\title{
Foreign Direct Investment 2013-2014: Destination Poland? An Update and Appraisal
}

\author{
Richard J. Hunter, Jr. ${ }^{1, *}$ \& Leo V. Ryan, C.S.V. ${ }^{2}$ \\ ${ }^{1}$ Department of Economics and Legal Studies, Seton Hall University, South Orange, N.J., \\ U.S.A. 07079 \\ ${ }^{2}$ Department of Management (Emeritus), DePaul University, Arlington Heights, Ill., U.S.A. \\ 60004 \\ *Corresponding author: Department of Economics and Legal Studies, Seton Hall University, \\ 400 South Orange Ave., South Orange, N.J., U.S.A. 07079 \\ Tel: 1-973-761-9511 E-mail: hunterri@shu.edu
}

Received: August 19, 2013 Accepted: September 16, 2013 Published: October 13, 2013

doi:10.5296/rae.v5i4.4151 URL: http://dx.doi.org/10.5296/rae.v5i4.4151

\begin{abstract}
This article is a discussion of the role and importance that foreign direct investment (FDI) has played in the Polish economy in light of the process of economic transformation accomplished in Poland since 1989. Much of the background information has been extrapolated from our prior research into the topic conducted over the past thirty years. The article discusses the positive aspects of FDI, outlines its main "players" in the Polish economy, offers suggestions relating to necessary preconditions for successful FDI activities, and describes the introduction of FDI within the larger context of economic reforms in Poland that dealt with the negative derivative traits of the former command-and-control economy.
\end{abstract}

Keywords: FDI; Economic Transformation; Monocentric System; PAIiIZ 


\section{Introduction}

Foreign Direct Investment, more commonly known as FDI, occurs with the purchase of "the physical assets or a significant amount of the ownership (stock) of a company in another country to gain a measure of management control." (Hunter, 2012/2013, Chapter 7; Hunter \& Ryan, 2012, p. 594.) Ordinarily, FDI inflows are counted from a 10 percent stock ownership in a company abroad. FDI may be distinguished from a more traditional type of investment termed portfolio investment (also called passive investment) because in a passive investment the investor is not seeking a degree of control in a company but only a return on investment. Examples of portfolio investment may be the purchase of corporate debt securities, mutual funds, stocks, bonds, interest-bearing bank accounts, treasury bills, and promissory notes. In Poland, an example of a passive investment would be an investment in one of the National Investment Funds or NIFS or the variety of stocks that are now listed on the Warsaw Stock Exchange. As an active form of investment, FDI may take the form of a merger-and-acquisition activity with an existing company or entity (often referred to as a "Brownfield" activity where the purchaser acquires an ongoing business operation), or may take the form of creating an entirely new investment-literally from the "ground up" (often referred to as a "Greenfield" activity).

\subsection{Impact of Foreign Direct Investment}

Professor Jack Behrman has served as a consultant to the United Nations Centre on Science and Technology for Development. Berman is a long-time expert in foreign direct investment. Dr. Behrman has identified the potential positive impacts of foreign direct investment inflows on host countries. Many of these impacts are especially relevant to the Polish experience. Among the positive impacts he lists:

- Increased domestic capital formation;

- Technology and management skill transfer;

- Regional and sectoral development;

- Fostering internal competition and entrepreneurship;

- Favorable effect on balance of payments; and

- Increased domestic employment, especially in lagging or "sunset" industries, such as those that use outdated and obsolete technologies or employ low-wage, low-skill employees. In Poland, it was hoped that FDI would include steel, coal, and shipbuilding - industries especially hit hard in the economic transition process.

From the start of the process of economic transformation in Poland in the fall of 1989, attracting FDI has been considered as a main policy objective of nearly all political parties and parliamentary configurations that have governed Poland and of all the individuals who have held the critical position of Minister of Finance in the Polish government. The most important of these individuals, no doubt, was Leszek Balcerowicz, who held the position of Minister of Finance and Deputy Prime Minister in the government of Prime Minister Tadeusz 
Mazowiecki. Mazowiecki came into office in the summer of 1989 after the Round Table talks had led to the semi-free parliamentary elections in the spring of 1989 and the failure of President Wojciech Jaruzelski to secure the election of his own candidate (General Kiszczak) for the position.

Minister Balcerowicz was a Professor of Economics at the Warsaw Institute of Economics. Balcerowicz had graduated from the Faculty of Foreign Trade of the Central School of Planning and Statistics - now the Warsaw School of Economics - which had served as the chief conduit to a bureaucratic or policy career in the former communist nomenklatura system. Perhaps more importantly, between September 1972 and January 1974, Balcerowicz had studied business administration at St. John's University in New York City, earning an MBA in 1974. In 1978, Balcerowicz presciently had established a "think tank" composed of ten young economists who would meet regularly to discuss and debate potential programs and prospects for economic reform. These informal meetings would no doubt shape the program of transformation adopted by the Mazowiecki government when it assumed power and greatly influenced all post-1989 Polish governments - both positively and negatively in their policy assessments and planning on how they should proceed in the processes of transformation. (E.g., Sachs, 1993; Balcerowicz, 1995). Minister Balcerowicz was able to bring together an eclectic team to tackle the critical issues confronting the near collapse of the Polish economy in the fall of 1989.

\subsection{The Command-and-Control Economy and Reform}

Minister Balcerowicz had identified certain derivative traits of the command-and-control economy that would be in need of immediate reform if Poland were to truly set out on a new economic path. These included:

- Administrative price fixing by central authorities;

- Isolation of domestic producers from foreign markets;

- Excessive regulation of imports through licenses and import quotas;

- The tendency by central planners to engage in "import substitution," often accomplished through rationing of goods, interminable queues and lines, and the widespread use of coupons for a wide variety of consumer staples such as milk, meat, sugar, paper products, etc.;

- "Soft budget constraint" in which targets of planning were revised downward or inputs significantly increased in order to meet plan targets, often based on political connections, politics, and not economic necessity;

- The lack of any true commercial and financial institutions;

- Monopolization of the state sector due to extreme organizational concentration, the centralization of organizational rights, and the lack of foreign competition; and perhaps most importantly,

- The lack of any motivation mechanisms for either line managers or workers. 
Early in the process of economic transformation, Minister Balcerowicz decided on a definitive strategy of transformation (Hunter \& Ryan, 2009) that would be based on two overarching considerations: A market economy was preferred over a centrally planned economy and a private market economy was preferred over so-called "market socialism" that was adopted in China. (Hunter \& Blodgett, 2009). In retrospect, these were fateful decisions that would uniquely shape the course of economic reform for nearly twenty-five years and which are still hotly debated today in Polish society.

\subsection{Elements of Polish Reform}

The program of economic reform would be based on five philosophical pillars of economic transformation which included: (1) rapid transformation of the monocentric system of state central planning into a private functioning market economy; (2) liberalization of economic functions, especially in relation to foreign trade and foreign direct investment (Hunter \& Ryan, 1997); (3) privatization of state-owned enterprises (SOEs) (Hunter \& Ryan, 2007); (4) construction of an effective social safety net; and (5) mobilization of international financial assistance [IMF, World Bank] to support the process. (Sachs, 1993).

Mirroring the Balcerowicz-Sachs model, Poland undertook the following concrete actions as the main components of its process of economic reform:

- Liberalizing prices from state control, opening up of the foreign trade régime and the Polish market to the infusion of Foreign Direct Investment, and formalizing and simplifying the requirements for market entry by those desiring to participate in the market;

- Stabilizing inflation, regularizing public finance, and managing the burden of foreign debt (which had reached $\$ 42$ billion dollars);

- Effecting changes in the economy leading to privatization of state property and to an increase in the nature and volume of international trade;

- Remodeling and upgrading the important social-safety net, most especially, the pension, education, social insurance, and unemployment insurance systems;

- Assuring eventual full convertibility of the Polish złoty;

- Gaining extensive external assistance (Hunter \& Ryan, 1998, pp. 82-84) of the International Monetary Fund (IMF), and the "London" (private commercial creditors) and "Paris" Clubs (public creditors); and

- Creating new market institutions, reestablishing a commercial code and a revised tax code, recognizing private property rights (Hunter, Ryan \& Nowak, 1995), and creating a financial and capital market sector (perhaps, most importantly, the creation of a viable stock market (de la Rosa, Crawford \& Franz, 2004); Ryan, 1997), and a properly functioning central bank). 
Proving the wisdom of Minister Balcerowicz's plans, at least as they have involved attracting FDI into the Polish economy, since the fall and early winter of 1989, with the adoption of the Balcerowicz Plan, foreign investors have injected more than $\$ 110$ billion into the Polish economy. Actually, Poland had limited choices. One of the main reasons for the emphasis in Poland on attracting foreign capital and FDI into the Polish economy was that there were few domestic options available in 1989 for a rapid and radical transformation of the Polish economy that all parties agreed would be absolutely necessary if Poland were to rid itself of its destructive command-and-control economy. Unfortunately, this was the case not only for Poland but for all of the nations in Central and Eastern Europe that had been trapped within the Soviet economic model of state central planning.

\section{Poland and FDI}

Almost from the beginning of the transformation in 1989-1990, Poland was considered as an attractive destination for FDI because of the existence of three inter-related factors: low cost but qualified labor; long-term market potential or yields greater than could be achieved domestically; and access to a wide variety of natural resources. Nearly a quarter-century later, these are still considered as essential preconditions to any successful effort at attracting FDI today.

More recently, the Federation of International Trade Associations reported on the main positives for Polish FDI as follows:

"A fast-growing economy, location in central Europe, a multilingual work force and cheap labor costs make Poland an internationally attractive country. Poland also enjoys a well managed healthy economy, which is withstanding the crisis better than other European countries. Unlike other Central European countries, its population did not have to resort to loans in foreign currencies, in particular Swiss, a fact which protects the population from maximum debt." (Federation of International Trade associations, 2011).

However, once the initial rush to foreign investment had occurred upon the opening of the economy to trade and investment, continued success would only be guaranteed due to the successful interrelation of several investment factors: few restrictions on FDI would be imposed in terms of targeted investments; "national treatment" would be offered to FDI, regardless of the country of origin; a relatively sound "company law" or commercial code would be created, as well as transparent customs and tariff procedures; the Polish government would continue to foster and nurture FDI activities; and Poland would be required to adopt an understandable and "perceived as fair" tax code conducive to foreign investment. (Hunter, Ryan \& Shapiro, 2003, pp. 46-48). 


\section{The Polish Record}

Over the past decade, the main investors which have located their capital in Poland are as follows: Germany with $16.4 \%$ of total FDI amount, the Netherlands with $16.1 \%$, Sweden with $13.44 \%$ and Luxemburg with $11.14 \%$. In 2011, the greatest number of projects came from the USA (36), the UK (15), South Korea (14) and China (13). (Official Promotional Website, 2011). The main objects of FDI were financial, legal, and accounting consulting companies; real estate companies; trade and companies engaged in "repair"; and industrial processing companies.

What is the recent history of FDI in Poland? A main source of up-to-date information on investment has been the European Attractiveness Survey (2013) conducted on an annual basis by the consulting firm of Ernst \& Young, which is very active in Poland providing accounting and a wide range of business consulting services.

In 2012, Poland ranked first in terms of attractiveness in the region of Central and Eastern Europe, according to $37 \%$ of the more than 800 international decision-makers who made up the poll. The Czech Republic finished second with $15 \%$ of respondents naming it. (In the region of Western Europe, Germany still ranks first with 38\%, followed by France with $17 \%$.)

Standing out in the statistics were two points. First, in 2012, 13,111 jobs were created in the Polish market or about 67\% more than were created in 2011. This ranks Poland in third place behind Great Britain and Russia, but ahead of both Germany and France.

Second, the number of new investment project (148) increased by $22 \%$ - the highest number and percentage increase in Europe on both counts. (In terms of the global economy, not unsurprisingly, China remains the most attractive over-all location for FDI, followed by Western Europe, North America, and Central and Eastern Europe.)

The Ernst \& Young survey was not alone in touting the Polish success story. In fact, a business climate survey conducted by the Polish-German Chamber of Industry and Commerce reaffirmed that Poland had outdistanced all other countries in the region in terms of investment attractiveness. Poland scores 4.87 on a maximum scale of 6 points, followed by the Czech Republic with 4.17 points, and Slovakia, with 3.99 points on the same 6 point scale. (Ratajczyk, 2013).

What were some of the main reasons cited in the recent surveys and which can be deduced from economic data that might account for Poland's position? Poland's membership in the European Union remains a decided plus. Up until recently, Poland's economy had not been as severely affected by the global financial crisis. At the end of 2012, Poland's public sector debt amounted to $57 \%$ of GDP, as compared to an EU average of $84.9 \%$. In fact, throughout the most recent five-year period (2008-2012), Poland's economy, as measured in GDP, grew at the following positive rates: 2008- 5.1\%; 2009- 1.8\%; 2010- 3.9\%; 2011- 4.5\%; and 2012$2.0 \%$. (PAIiIZ, 2013). The singular attractiveness of Poland's labor market was also seen as a positive. Surveys cited Polish workers for their technical qualifications, level and degree of education, enhanced productivity and personal motivation. In addition, although still 
important in maintaining a world-wide competitive balance, and in recognition of the fact that large-scale industrial projects are becoming fewer in the European market, Poland is seen as an attractive location in the "shared service" (providing internal services to an organization) and in small-to-medium production.

This is not to say that there has not been a wide mix of investment projects throughout Poland in the recent past. For example, in addition to several industrial-based projects, business service centers have recently been established in Krakow, Wroclaw and Lodz.

One of the constant factors that has existed in promoting FDI in Poland has been the work of the Polish Information and Foreign Investment Agency or PAIiIZ, which literally reaches thousands of potential investors. The website is well organized and contains useful information relating to such topics as "Why Poland?" core economic data, publications, specific Brownfield and Greenfield investment opportunities, publications, databases, Special Economic Zones (SEZs), economic sectors, regional opportunities, and important information on Polish implementing law.

Precisely because domestic options were limited when Poland began its process of economic transformation nearly twenty-five years ago, Poland has adopted a thoroughly professional and targeted program designed to produce the type of economy necessary to complete and sustain its long process of economic change, reform, and modernization.

\section{Acknowledgment}

This research was supported by a grant from the Institute for International Business, Seton Hall University.

\section{References}

Balcerowicz, L. (1995). Socialism, Capitalism, Transformation. New York: Central European Press.

Behrman, J. (1970). National interests and the multinational enterprise. Englewood Cliffs, N.J.: Prentice-Hall.

Behrman, J. (1984). Industrial policies: international restructuring and transnationals. Lexington, Mass.: Lexington Books.

Bossak, J., \& Kalicki, K. (1994). Poland's Agreement with the London Club. In Poland: international economic report (Bossak, J, ed.). Warsaw: World Economy Research Institute.

Consulate General of the Republic of Poland. (2010). FDI in Poland. Retrieved July 2010 from www.montreal.trade.gov.pl/en/aktualnosci/article/a,11625,.html

De la Rosa, D., Crawford, D., \& Franz, D. (2004). Trading on the Warsaw Stock Exchange 
- From Reopening in 1991-2000. Journal of International Accounting, Auditing and Taxation, 13, 121-134. http://dx.doi.org/10.1016/j.intaccaudtax.2004.09.003

Ernst \& Young. (2012). European Attractiveness Survey. Retrieved August 13, 2013 from http://www.ey.com/GL/en/Issues/Business-environment/2012-European-attractiveness-s urvey

Federation of International Trade Associations. (2011). Retrieved August 9, 2013 from www.fita.org/countries/investing_40.html

German-Polish Chamber of Industry and Commerce. (2013). Retrieved August 13, 2013 from http://www.linkedin.com/groups/GermanPolish-Chamber-Industry-Commerce-AHK

Hunter, R.J. Jr., \& Blodgett. M. (2009). Foreign Direct Investment, Trade, and China's Competition Law. Denver Journal of International Law and Policy, 37(2), 201-231.

Hunter, R.J. Jr., \& Ryan, L.V. (2009). Poland in 1989: Enter Tadeusz Mazowiecki and the Creation of the Balcerowicz Plan. Research Journal of International Studies, 11, Article 4. Retrieved from http://www.eurojournals.com/international_studies.htm

Hunter, R.J., Jr., \& Hrechak, A. (1993). Federal Income Tax Implications for U.S. Employees Working Outside the United States. Business Law Review, 26, 29-38.

Hunter, R.J., Jr., \& Hrechak, A. (1994). Several Tax Breaks for Those Working Abroad. Taxation for Accountants, 282-286.

Hunter, R.J., Jr., \& Ryan, L.V. (1998). From Autarchy to Market. Westport, Conn: Praeger.

Hunter, R.J., Jr., \& Ryan, L.V. (2006). Transition in the Polish Economy. In Developmental Entrepreneurship: Adversity, Risk, and Isolation (Galbraith, C.S. \& Stiles, C.H., eds.), Oxford, U.K.: Elsevier, 71-77. http://dx.doi.org/10.1016/S1074-7877(06)05005-7

Hunter, R.J., Jr., \& Ryan, L.V. (2007). A Field Report on the Background and Processes of Privatization in Poland. Global Economy Journal, 8(2), Article 5. Retrieved from http://www.degruyter.com/view/j/gej

Hunter, R.J., Jr., \& Ryan, L.V. (2011). Polish Election 2010: Possible Political and Economic Implications. Sarmatian Review, 31(1), 1547-1549.

Hunter, R.J., Jr., \& Ryan, L.V. (2012). An Update on Polish Foreign Direct Investment: The Story of Intrall Rus: A Case Study on Transformation." International Journal of Academic Research in Business and Social Sciences, 2(1), 594-603.

Hunter, R.J., Jr. (2012/2013). International perspectives [Course book]. South Orange, N.J.: Seton Hall University (Chapter 7).

Hunter, R.J., Jr. Shapiro, R., \& Ryan, L.V. (2003). Foreign Direct Investment in Poland. The Polish Review, 48(3), 303-316.

Hunter, R.J., Jr., Ryan, L.V., \& Nowak, A. (1995). Legal Aspects of the Transformation Process in Poland: Business Association Forms. The Polish Review, 40(4), 387-407. 
Hunter, R.J., Jr., Ryan, L.V., \& Shapiro, R.E. (2003). Enter Leszek Balcerowicz. In Poland: A Transitional Analysis. New York: PIASA Press, 17-21.

Hunter, R.J., Jr., Ryan, L.V., \& Shapiro, R.E. (2003). Poland: A transitional analysis. New York: PIASA Press.

Moran, T.H. (1998). Foreign direct investment and development: The new policy agenda for developing countries and economies in transition. New York: Barnes and Noble.

National Bank of Poland. (2013). FDI inflow. Retrieved from http://www.nbp.pl/Homen.aspx?f=srodeken.htm

Official Promotional Website of the Republic of Poland. (2011). Retrieved July 17, 2011 from http://www.wbj.pl/article-60385-polands-2012-fdi-similar-to-2011-level.html

Polish Information and Foreign Investment Agency (PAIiIZ). (2011). Invest in Poland. Retrieved July 18, 2013 from http://www.paiz.gov.pol

Polish Information and Foreign Investment Agency (PAIiIZ). (2013). Retrieved August 13, 2013 from http://www.paiz.gov.pl/

Ratajczyk, A. (2013). Poland Most Attractive in the Region. The Warsaw Voice, July 2013, 54.

Ryan, L.V. (1997). The Tempestuous Warsaw Stock Market: 1991-1996, in International business in the new millennium (Fatimi, K., ed.). Laredo, Texas: Texas A\&M International University, III, 687-706.

Sachs, J. (1993). Poland's march to the market economy. Cambridge, Mass.: MIT University Press.

\section{Copyright Disclaimer}

Copyright reserved by the author(s).

This article is an open-access article distributed under the terms and conditions of the Creative Commons Attribution license (http://creativecommons.org/licenses/by/3.0/). 